\title{
Effect of lifestyle interventions on diabetic peripheral neuropathy in patients with type 2 diabetes, result of a randomized clinical trial
}

\author{
Tip 2 diyabetli hastalarda yaşam tarzı müdahalelerinin diyabetik periferik \\ nöropati şiddeti üzerine etkisi, randomize klinik çalışmanın sonucu
}

(1) Haleh GHAVAMI, (1) Moloud RADFAR, (1) Soraya SOHEILY, (1) Shams Aldin SHAMSI, @ Hamid Reza KHALKHALI

\begin{abstract}
Summary
Objectives: Diabetic peripheral neuropathy (DPN) is the most common and troublesome complication of diabetes leading to great morbidity and resulting in a huge economic burden for diabetes care. Over half of people with diabetes develop neuropathy. Also, DPN is a major cause of reduced quality of life due to pain, sensory loss, gait instability, fall-related injury, and foot ulceration and amputation. The aim of this study was evaluating the effects of lifestyle interventions on diabetic neuropathy severity in diabetes type 2 outpatients.
\end{abstract}

Methods: This clinical trial conducted on 74 patients with DPN that divided with random allocation into intervention or control group. The lifestyle interventions applied in the intervention group beginning four educational sessions on lifestyle that emphasize strategies for lowering blood sugar, increasing physical activity, promoting weight loss, prudent diet, and foot caring. Each session was lasted for 1.5 hour. Then patients followed for 12 weeks. During this period, they received counseling on mentioned lifestyle interventions. DPN severity in both groups measured using modified Toronto Clinical Neuropathy Score (mTCNS) at the beginning of study and at the end of counseling for 12 weeks.

Results: Comparing differences of mean of DNP severity before and after lifestyle intervention between two groups of study, there was a significant difference $(p<0.001)$. DNP severity in control group had not any change or it increased in some participants, but DNP decreased in intervention group, after applying lifestyle intervention.

Conclusion: Lifestyle interventions can contribute to reducing DPN severity, and consequently decreasing neuropathic pain.

Keywords: DPN severity; lifestyle interventions; modified Toronto Clinical Neuropathy Score (mTCNS).

\section{Özet}

Amaç: Diyabetik periferik nöropati (DPN) diyabetin en sık karşılaştı̆̆ı ve sıkıntılı bir komplikasyondur ve büyük bir morbiditeye yol açar ve diyabet bakımı için büyük bir ekonomik yük oluşturur. Nöropati diyabetli kişilerin yarısından fazlasında gelişir. Ayrıca, ağrı, duyusal kayıp, yürüme instabilitesi, düşme ile ilişkili yaralanma, ayak ülseri ve amputasyon nedeniyle, DPN yaşam kalitesinin azalmasının temel nedenidir. Bu çalışmanın amacı, ayakta tedavi edilen diyabet tip 2 hastalarda; yaşam tarzı müdahalelerinin diyabetik nöropati şiddeti üzerine etkilerini değerlendirmekti.

Gereç ve Yöntem: Bu klinik çalışma, DPN'si olan ve rastgele yöntemi ile; müdahale ya da kontrol grubuna ayrılanan, 74 hasta üzerinde gerçekleştirildi.Kan şekerini düşürmek, fiziksel aktiviteyi arttırmak, kilo kaybını teşvik etmek, ihtiyatlı beslenme ve ayak bakımı için stratejileri vurgulayan yaşam tarzı üzerine dört eğitim oturumu ile başlanan yaşam tarzı müdahaleleri müdahale grubunda uygulanmaya başladı. Her eğitim seansi 1.5 saat sürdü. Daha sonra hastalar 12 hafta boyunca takip edildiler ve bu dönemde yaşam tarzı müdahaleleri konusunda danışmanlık aldılar. Her iki grupta da DPN`nin şiddeti, çalışmanın başlangıcında, ve 12 haftalık danışmanlık sonunda modifiye Toronto Clinical Neuropathy Score (mTCNS) kullanılarak ölçüldü.

Bulgular: Çalışma gruplarının DNP şiddeti, yaşam tarzı müdahaleleri öncesi ve sonrası, ortalamaları arasındaki farklılıkların karşılaştıııldığında anlamlı bir fark bulundu ( $p<0.001)$.Yaşam tarzı müdahaleleri uygulandıktan sonar kontrol grubunun DNP şiddeti herhangi bir değişiklik göstermemiş̧ir ya da bazı katılımcılarda DNP şiddeti artmıştır, ancak yaşam tarzı müdahaleleri uygulandıktan sonra müdahale grubunda DNP azalmıştır.

Sonuç: Yaşam tarzı müdahaleleri, DPN şiddetinin azaltılmasında ve sonuç olarak nöropatik ağrının azaltılmasında katkıda bulunabilir.

Anahtar sözcükler: DPN şiddeti; yaşam tarzı müdahaleleri; modifiye Toronto Klinik Nöropati Skoru (mTCNS).

Urmia University of Medical Sciences Faculty of Nursing and Midwifery, Urmia, Iran

Submitted (Başvuru tarihi) 22.06.2018 Accepted after revision (Düzeltme sonrası kabul tarihi) 20.09.2018 Available online date (Online yayımlanma tarihi) 24.10.2018

Correspondence: Dr. Shams Aldin Shamsi. Nursing and Midwifery Faculty of Urmia University of Medical Sciences, Pardis Nazlou, 11 km of Nazlou Road Urmia, Iran.

Phone: +989143416092 e-mail: ghavami.h@umsu.ac.ir

(C) 2018 Turkish Society of Algology 


\section{Introduction}

Diabetes mellitus (DM) is one of the largest global public health emergencies of the 21st century. Approximately 415 million adults have DM and by 2040 this number will rise to 642 million. ${ }^{[1]}$ Diabetic neuropathies are a heterogeneous group of disorders of varying etiology and clinical presentation. Diabetic neuropathy with a prevalence of approximately $60 \%$ is the most common form of neuropathy in developed countries and may affect about half of all patients with diabetes mellitus, contributing to substantial morbidity and mortality and resulting in a huge economic burden. The most common form is symmetrical diabetic peripheral neuropathy (DPN), which mainly affects the lower extremities and is a major cause of morbidity because of its effects on risk for subsequent ulcers, amputation and disability. ${ }^{[1-3]}$ Diabetic neuropathy (DN) severely decreases patients' quality of life and the quality of diabetes self-management and, in consequence, is worsening the prognosis of other diabetes complications. ${ }^{[1]}$ Diabetic peripheral neuropathy (DPN) was defined by the presence of at least two of the following three characteristics: (a) pain, paresthesia, or numbness; (b) absence of tendon reflexes; (c) abnormal malleoli vibration perception threshold. ${ }^{[4]}$

Studies show that improved glycemic control improves nerve function in diabetic patients. ${ }^{[5-9]}$ In addition, there is good evidence that intensive glycemic control reduces the risk of developing diabetic neuropathy in patients with type 1diabetes and may reduce the risk in patients with type 2 diabetes. ${ }^{[9-11]}$ Unhealthy behaviors (such as comfort eating, poor diet choices, smoking, and inactivity) implicated in up to $40 \%$ of premature deaths in the U.S. and contribute to persistent disparities in health. On the other hand, healthy lifestyles are broad and potentially unobservable orientations that organize patterns of behaviors that derive from knowledge and norms about what constitutes healthy, stress relieving, or pleasurable behaviors. ${ }^{[12]}$

The aim of this study was to determine the effect of lifestyle interventions (based on; lowering blood sugar, increasing physical activity, lowering weight, and proper caring of feet) on the severity of diabetic peripheral neuropathy in patients with type 2 diabetes. We hypothesized that this lifestyle interven- tions program would reduce the severity of diabetic peripheral neuropathy progression in the intervention group.

\section{Material and methods}

\section{Design}

This study is a randomized clinical trial with a prepost-test design. This study obtained the approval from the Research Ethics Committee of Urmia University of Medical Sciences (Reference No. IR.UMSU. REC.1393.11). Patients who met the eligibility criteria invited to participate. Eligible participants were systematically randomized by computer into the control or lifestyle intervention group. Then, participants received the introductory instructional guide and all participants signed an informed-consent form (Fig. 1).

\section{Participant recruitment and eligibility criteria}

Over a 12 months period study participants were recruited using face-to-face strategy. Eligibility criteria included; Adults ( $\geq 18$ years and older) with diabetic neuropathy, without any ulcer on their foot, and living in Urmia. Patients were excluded if they had known non-diabetic causes of neuropathy (for example, vitamin deficiencies, uremia, thyroid disease, lumbar or cervical radiculopathy, inflammatory neuropathy or presence of alcoholism). The sample size goal of 80 (half in each treatment group) was derived a priori with $G *$ Power software version 3.1.9.2 (Universitat Kiel, Germany) for analysis of covariance with an effect size of $0.25, p \leq 0.05$, and $95 \%$ power. During the study three participants from each group discontinued their participation.

\section{Instruments}

Demographic information questionnaire, and the modified Toronto Clinical Neuropathy Score (mTCNS) used for data collection. For measuring the severity of neuropathy, participants were allowed a 10-minute acclimatization period in constant room temperature $\left(24 \pm 1^{\circ} \mathrm{C}\right)$ after they had removed their socks and shoes.

The Toronto Clinical Neuropathy Score (TCNS) is a sensitive scoring system used to diagnose diabetic neuropathy, and to measure changes in such early diabetic sensorimotor polyneuropathy (DSP) pathophysiology. TCNS can be used as an inexpensive bedside screening tool. ${ }^{[13,14]}$ The TCNS was modified (into 
Table 1. Comparison the severity of DPN between two groups of study before and after lifestyle intervention

\begin{tabular}{|c|c|c|c|c|c|}
\hline \multirow[t]{2}{*}{ Neuropathy score } & \multicolumn{2}{|c|}{ Control group } & \multicolumn{2}{|c|}{ Intervention group } & \multirow{2}{*}{$\begin{array}{c}\text { Results of independent } \\
\text { T test }\end{array}$} \\
\hline & Mean & SD & Mean & SD & \\
\hline Before intervention & 9.51 & 2.7 & 11.9 & 3 & $\mathrm{p}<0.001$ \\
\hline After intervention & 10.41 & 2.6 & 6.81 & 2.2 & $\mathrm{p}<0.001$ \\
\hline Difference of before- after & 0.89 & 0.73 & -5.1 & 1.2 & $\mathrm{p}<0.001$ \\
\hline
\end{tabular}

SD: Standard deviation.

the mTCNS) to better capture a categorical scale of simple sensory tests, which are better representative of the early dysfunction in DSP, and to eliminate reflex testing, which represent the late-stage pathophysiology of DSP, are highly variable between raters, age dependent and heavily weighted in the TCNS. The mTCNS, a clinical score with higher face validity for tracking mild to moderate DSP, has sufficient reliability and validity relative to its precursor TCNS for use in clinical research. ${ }^{[13]}$ mTCNS consists of graded symptoms (foot pain, numbness, tingling, weakness, ataxia and upper limb symptoms) and a sensory test (pinprick, temperature, light touch, vibration and position sense) score associated with DPN in the judgment of the examiner. The scale varies from 0 (no signs or symptoms) to 33 (maximal symptoms and signs). ${ }^{[15]}$

\section{Intervention}

The lifestyle interventions applied in the intervention group beginning 4 educational sessions on lifestyle that emphasize strategies for; lowering blood sugar, increasing physical activity, promoting weight loss, and feet caring. Each session was lasted for 1.5 hour. Then patients followed for 12 weeks. During this period, they received individualized counseling on mentioned lifestyle interventions. All participants of intervention group received individualized counseling with goals of reducing weight by $7 \%$, increasing weekly exercise to $150 \mathrm{~min}$, and proper daily feet caring. They received dietary counseling based on their preferences individually, too. Participants in the control group received their routine care and education, without any more education or consulting on lifestyle. Diabetic neuropathy symptom severity in both groups measured using Modified Toronto Clinical Neuropathy Score (mTCNS) at the beginning of study and at the end of counseling for 12 weeks.

\section{Results}

\section{Demographic variables of participants}

In the present study, results showed that $81.1 \%$ of participants in the control group, and $70.3 \%$ of intervention group were female. $29.7 \%$ of participants in control group, and $35.1 \%$ in intervention group were illiterate. In the control group, the mean and standard deviation of age were $(47.3 \pm 10.8)$ and in the intervention group, the mean of age were $(49.38 \pm 7.9)$ and there was no significant difference in age of participants between the two groups of study $(p=0.29)$. In the control group, the mean and standard deviation of diabetes duration is (16.89 \pm 5.4$)$ and in the intervention group, the mean and standard deviation of diabetes duration is $(19 \pm 4.6)$ and there was no significant difference in duration of diabetes between the two groups of study ( $p=0.07)$. A higher proportion of participants in both groups of study were married.

\section{Intervention impact measurement}

Based on the results of independent $t$-test, the mean of DPN severity was statistically significant before intervention between two groups of study, but considering before and after differences of the mean of DPN severity, there was significantly decrease in DPN severity of intervention group after the lifestyle intervention $(p<0.001)$ (Table 1).

Before and after differences of the mean of DPN severity in the intervention group is bigger than it in the control group (Table 1).

In the intervention group, the severity of neuropathy decreased from; severe to moderate, and from moderate to mild/ without neuropathy symptom, but in the control group, the severity of neuropathy did not change or progressed to a higher levels (Tables 2, 3). Comparing the severity of DPN in the intervention 
Table 2. Comparison the severity of DPN in the intervention group before and after lifestyle intervention

\begin{tabular}{|c|c|c|c|c|c|c|c|c|c|c|}
\hline \multirow[b]{2}{*}{ Before inter. } & \multicolumn{2}{|c|}{$\begin{array}{c}\text { Absence of } \\
\text { neuropathy } \\
\text { symptoms }\end{array}$} & \multicolumn{2}{|c|}{$\begin{array}{c}\text { Mild } \\
\text { neuropathy }\end{array}$} & \multicolumn{2}{|c|}{$\begin{array}{l}\text { Moderate } \\
\text { neuropathy }\end{array}$} & \multicolumn{2}{|c|}{$\begin{array}{c}\text { Severe } \\
\text { neuropathy }\end{array}$} & \multicolumn{2}{|c|}{ Total } \\
\hline & $\mathbf{n}$ & $\%$ & $\mathbf{n}$ & $\%$ & $\mathbf{n}$ & $\%$ & $\mathbf{n}$ & $\%$ & $\mathbf{n}$ & $\%$ \\
\hline Mild neuropathy & 6 & 100 & 0 & 0 & 0 & 0 & 0 & 0 & 6 & 100 \\
\hline Moderate neuropathy & 5 & 38.5 & 8 & 61.5 & 0 & 0 & 0 & 0 & 13 & 100 \\
\hline Severe neuropathy & 0 & 0 & 10 & 55.6 & 8 & 4.44 & 0 & 0 & 18 & 100 \\
\hline Total & 11 & 29.7 & 18 & 48.6 & 8 & 2.6 & 0 & 0 & 37 & 100 \\
\hline
\end{tabular}

DPN: Diabetic peripheral neuropathy; Inter.: Intervention.

Table 3. Comparison the severity of DPN in the control group before and after lifestyle intervention

\begin{tabular}{|c|c|c|c|c|c|c|c|c|c|c|}
\hline \multirow[b]{2}{*}{ Before inter. } & \multicolumn{2}{|c|}{$\begin{array}{c}\text { Absence of } \\
\text { neuropathy } \\
\text { symptoms }\end{array}$} & \multicolumn{2}{|c|}{$\begin{array}{c}\text { Mild } \\
\text { neuropathy }\end{array}$} & \multicolumn{2}{|c|}{$\begin{array}{l}\text { Moderate } \\
\text { neuropathy }\end{array}$} & \multicolumn{2}{|c|}{$\begin{array}{c}\text { Severe } \\
\text { neuropathy }\end{array}$} & \multicolumn{2}{|c|}{ Total } \\
\hline & $\mathbf{n}$ & $\%$ & $\mathbf{n}$ & $\%$ & $\mathbf{n}$ & $\%$ & $\mathbf{n}$ & $\%$ & $\mathbf{n}$ & $\%$ \\
\hline Mild neuropathy & 0 & 0 & 7 & 46.7 & 8 & 53.3 & 0 & 0 & 15 & 100 \\
\hline Moderate neuropathy & 0 & 0 & 0 & 0 & 17 & 100 & 0 & 0 & 17 & 100 \\
\hline Severe neuropathy & 0 & 0 & 0 & 0 & 0 & 0 & 5 & 100 & 5 & 100 \\
\hline Total & 0 & 0 & 7 & 18.9 & 25 & 67.6 & 5 & 13.5 & 37 & 100 \\
\hline
\end{tabular}

DPN: Diabetic peripheral neuropathy; Inter.: Intervention.

group, before and after lifestyle intervention presented in the Table 2; the severity of neuropathy decreased; from the severe to moderate, and from moderate level to mild or to absence of neuropathy symptom level. For example, before the intervention, there were 13 participants with moderate neuropathy, that 5 patients had not any neuropathy symptom (absent of neuropathy) and 8 of them had mild neuropathy, after the end of lifestyle intervention (Table 2).

Comparing the severity of DPN in the control group, before and after lifestyle intervention presented in the Table 3; the severity of neuropathy had not any change or it increased to a higher level of severity after the end of lifestyle intervention. For example, before the intervention, there were 15 participants with mild neuropathy, that DPN severity in 8 of them reached to moderate level and DPN severity in the rest of 7 patients had not any change after the end of lifestyle intervention (Table 3).

\section{Discussion}

Poor lifestyle choices, such as smoking, poor diet, lack of physical activity and inadequate relief of chronic stress are key contributors in the development and progression of preventable chronic diseases, including type 2 diabetes mellitus. Even though physicians encourage healthy lifestyle to help prevent or manage many chronic medical conditions, many patients are inadequately prepared to either start or maintain these appropriate, healthy changes.

This randomized controlled trial study was designed to clarify the effectiveness of Lifestyle Interventions on the severity of diabetic peripheral neuropathy in patients with type 2 diabetes. Our study findings support our priori hypothesis that lifestyle interventions with emphasize strategies for lowering blood sugar, increasing physical activity, promoting weight loss, prudent diet, and foot caring, would contribute to reducing DPN severity.

Our results are consistent with the study findings of Smit et al. ${ }^{[4]}$ on lifestyle intervention for pre-diabetic neuropathy in 2006, indicated; diet and exercise counseling for patients with impaired glucose tolerance results in cutaneous re-innervation and im- 


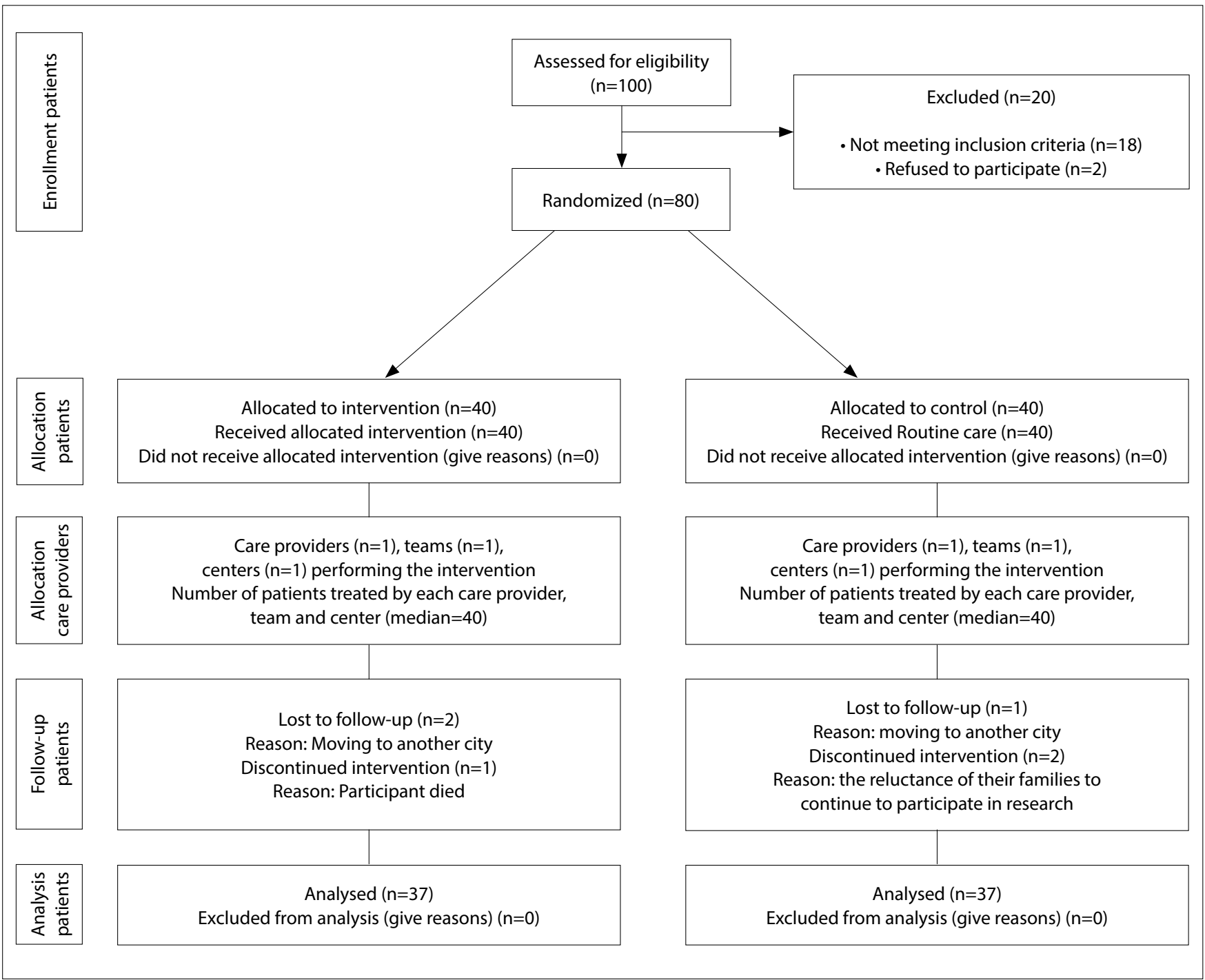

Figure 1. Consort flow diagram.

proved pain. Also, Juster-Switlyk and Smit in 2016 suggested that; weight loss and exercise are helpful strategies for patients with neuropathy in the setting of both diabetes and pre-diabetes. ${ }^{[16]}$ Also, our results is consistent with other studies which improvement in health status after lifestyle interventions have seen in their results such as; A) Study of Khanji et al. ${ }^{[17]}$ on lifestyle advice and interventions for cardiovascular risk reduction, B) Study of Howells et al. ${ }^{[18]}$ on the clinical impact of lifestyle interventions for the prevention of diabetes, C) Study of Kolb and Martin on Environmental/lifestyle factors in the pathogenesis and prevention of type 2 diabetes. ${ }^{[19]}$

Limitations: This study had some limitations: 1) participants were enrolled only from one hospital; 2) relatively short intervention time. It is suggested that other multi centers studies with longer intervention time be conducted.

\section{Conclusion}

Findings of this study showed that, despite the high levels of neuropathic disorders among diabetic patients, using low cost and safe methods such as lifestyle interventions, can contribute in reducing severity of diabetic peripheral neuropathy, and enhancing comfort among these patients. Traditionally, neuropathic pain prompts physicians to prescribe drugs (usually gabapentin and pregabalin) for DPN pain ${ }^{[20]}$ that may be associated with adverse effects, such as drug resistance, dependence and addiction. In this study, it demonstrated that lifestyle intervention would successfully contribute in reduction of DPN severity in patients with diabetic peripheral neuropathy.

Our findings have implications for clinical and policy decisions, as well as for the design for future studies with larger sample sizes and long period of time. In particular, our findings underscore the importance 
of healthy lifestyle in the management of diabetic patients with or at risk of diabetic peripheral neuropathy. Reduction in the severity of DPN following lifestyle intervention in this study can contribute in enhancing quality of life regarding DPN is a major cause of reduced quality of life due to pain, sensory loss, gait instability, fall-related injury, and foot ulceration and amputation.

\section{Acknowledgments}

This article extracted from a master's thesis. The researchers would like to express their thanks to the study participants.

\section{Conflict-of-interest issues regarding the authorship or article: None declared.}

\section{Peer-reiew: Externally peer-reviewed.}

\section{References}

1. Timar B, Timar R, Gaiță L, Oancea C, Levai C, Lungeanu D. The Impact of Diabetic Neuropathy on Balance and on the Risk of Falls in Patients with Type 2 Diabetes Mellitus: A Cross-Sectional Study. PLoS One 2016;11(4):e0154654.

2. Vinik A, Casellini C, Nevoret ML. Diabetic Neuropathies. Endotext - NCBI Bookshelf - NIH. Last Update: February 5, 2018. Available at: https://www.ncbi.nlm.nih.gov/books/ NBK279175/. Accessed Jun 11, 2018.

3. Look AHEAD Research Group. Effects of a long-term lifestyle modification programme on peripheral neuropathy in overweight or obese adults with type 2diabetes: the Look AHEAD study. Diabetologia 2017;60(6):980-8.

4. Smith AG, Russell J, Feldman EL, Goldstein J, Peltier A, Smith S, et al. Lifestyle intervention for pre-diabetic neuropathy. Diabetes Care 2006;29(6):1294-9.

5. Graf RJ, Halter JB, Pfeifer MA, Halar E, Brozovich F, Porte D Jr. Glycemic control and nerve conduction abnormalities in non-insulin-dependent diabetic subjects. Ann Intern Med 1981;94(3):307-11.

6. Holman RR, Dornan TL, Mayon-White V, Howard-Williams J, Orde-Peckar C, Jenkins L, et al. Prevention of deterioration of renal and sensory-nerve function by more intensive management of insulin-dependent diabetic patients. A two-year randomised prospective study. Lancet
1983;1 (8318):204-8.

7. Pietri $A$, Ehle $A L$, Raskin P. Changes in nerve conduction velocity after six weeks of glucoregulation with portable insulin infusion pumps. Diabetes 1980;29(8):668-71.

8. Kuwabara S, Ogawara K, Harrori T, Suzuki Y, Hashimoto N. The acute effects of glycemic control on axonal excitability in humandiabetic nerves. Intern Med 2002;41(5):360-5.

9. Feldman EL. Pathogenesis and prevention of diabetic polyneuropathy. Available at: https://www.uptodate. com/contents/pathogenesis-and-prevention-of-diabeticpolyneuropathy Accessed: Oct 30, 2018.

10. Callaghan BC, Hur J, Feldman EL. Diabetic neuropathy: one disease or two? Curr Opin Neurol 2012;25(5):536-41.

11. Peltier A, Goutman SA, Callaghan BC. Painful diabetic neuropathy. BMJ 2014;348:g1799.

12. Saint Onge JM, Krueger PM. Health Lifestyle Behaviors among U.S. Adults. SSM Popul Health 2017;3:89-98.

13. Bril V, Tomioka S, Buchanan RA, Perkins BA, mTCNS Study Group. Reliability and validity of the modified Toronto Clinical NeuropathyScore in diabetic sensorimotor polyneuropathy. Diabet Med 2009;26(3):240-6.

14. Udayashankar D, Premraj SS, Mayilananthi K, Naragon V. Applicability of Toronto Clinical Neuropathy Scoring and its Correlation with Diabetic Peripheral Neuropathy: A Prospective Cross-sectional Study. J Clin Diagn Res 2017;11(12):OC10-3.

15. Yoshioka K, Okada H. Useful application of the Neuropad test for assessment of diabetic polyneuropathy. Intern Med 2012;51(23):3241-5.

16. Juster-Switlyk K, Smith AG. Updates in diabetic peripheral neuropathy. F1000Res 2016;5. pii: F1000 Faculty Rev-738.

17. Khanji MY, van Waardhuizen CN, Bicalho VVS, Ferket BS, Hunink MGM, Petersen SE. Lifestyle advice and interventions for cardiovascular risk reduction: A systematic review of guidelines. Int J Cardiol 2018;263:142-51.

18. Howells L, Musaddaq B, McKay AJ, Majeed A. Clinical impact of lifestyle interventions for the prevention of diabetes: an overview of systematic reviews. BMJ Open 2016;6(12):e013806.

19. Kolb $H$, Martin S. Environmental/lifestyle factors in the pathogenesis and preventionof type 2 diabetes. BMC Med 2017; 15(1):131.

20. Goodman CW, Brett AS. Gabapentin and Pregabalin for Pain - Is Increased Prescribing a Cause for Concern? N Engl J Med 2017 377(5):411-4. 